\title{
Decision Support System for Selecting Halal-Certified Restaurant Using Analytical Hierarchy Process on Android Platform
}

\author{
$1^{\text {st }}$ Nenny Anggraini ${ }^{1}, 2^{\text {nd }}$ Luh Kesuma Wardhani ${ }^{1}, 3^{\text {th }}$ Nurul Faizah Rozi ${ }^{1}, 4^{\text {th }}$ Silfy Ashyia \\ Achtar $^{1}, 5^{\text {th }}$ M. Tabah Rosyadi ${ }^{1}$ \\ \{nenny.anggraini@uinjkt.ac.id ${ }^{1}$, luhkesuma@uinjkt.ac.id ${ }^{1}$, nurul.faizah@uinjkt.ac.id ${ }^{1}$ \}
}

UIN Syarif Hidayatullah Jakarta, Indonesia ${ }^{1}$

\begin{abstract}
Nowadays, Moslem people in Indonesia pay serious attention to halal-food certified restaurant. According to online data from LPPOM Majelis Ulama Indonesia, there are only 5,663 halal-certified restaurants in Indonesia, meanwhile culinary industries are growing fast recently. We can find a lot of restaurants and street food stalls easily in town. Moslem people must be very carefully in selecting restaurant to get halal food. It will be easier for Moslem people if they can get more information about halalfood restaurant in a certain place. By utilizing advance technology, a decision support system for selecting halal food restaurant in android platform can be a solution for Moslem people in order to simplify selection. This system, which was build using incremental system development, recommends some alternative of halal-food certified restaurants in Jakarta based on variations of menu, price and service of restaurants which were processed by Analytical Hierarchy Process (AHP) method. It can be operated through android smartphone easily therefore everyone can use it. After evaluated using unit testing, this decision support system can be accepted by user and recommend Dunkin' Donut as the best alternatives for halal food certified restaurant in Jakarta.
\end{abstract}

Keywords: DSS, decision support system, AHP, halal-food certified restaurant, android.

\section{Introduction}

Every Muslim is obliged to consume halal food and drinks, leave things that are subhat (doubtful), and keep away from the haram. In accordance with the Surah Al-Baqarah (2:168)

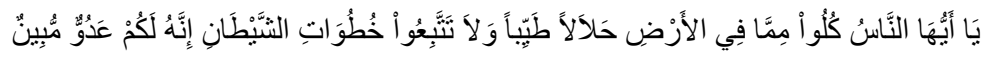

"O mankind, eat from whatever is on earth [that is] lawful and good and do not follow the footsteps of Satan. Indeed, he is to you a clear enemy".

Therefore Indonesia as a country with a majority of Muslims has developed an institution that is authorized to research, study, analyze and decide whether a food, medicine and cosmetics product is safe for consumption and in accordance with the Islamic religion, namely Lembaga Pengkajian Pangan, Obat-obatan, Kosmetika Majelis Ulama Indonesia (LPPOM MUI).

The important role of LPPOM MUI as an institution that informs whether a product is halal or not, is to become a benchmark for Muslims in Indonesia in choosing products. To 
make it easier for the Indonesian people to provide information about halal or haram of food, medicine and cosmetics products, LPPOM MUI has several branches spread across several provinces, one of which is LPPOM MUI in DKI Jakarta province.

Moslem people in Indonesia pay serious attention to halal food certified restaurant. According to online data from LPPOM Majelis Ulama Indonesia, there are only 5,663 halalcertified restaurants in Indonesia, meanwhile culinary industries are growing fast recently. Moslem people must be very carefully in selecting restaurant to get halal food.

Utilizing advance technology, a decision support system (DSS) was developed to ease Moslem people in selecting halal-food certified restaurant. This DSS was build in android platform, which can used easily by many people through smartphone. To recommend some alternatives of halal-food certified restaurants, this system implement AHP method, which has good performance in recommending alternatives in decision support system [1]

As a first step, this DSS recommends some alternative of halal-food certified restaurant in Jakarta. We use three criteria in composing alternatives, namely variations of menu, price of food and service of restaurants. The whole system was developed using incremental method.

More discussion about this research is organized as follows. Section 2 describes some literature of this research. Section 3 methods that used in this research. Section 4 is about the result and discussion, which describe development process of decision support system. The results of development process and its discussions are also described here. Finally, is section 5, where the conclusions are described.

\section{Literature}

\subsection{Decision Support System}

Decision Support System was first introduced in the early 1970s by Michael S. Scott Morton with the term Management Decision System. The concept of decision support is characterized by an interactive computer-based system that helps decision makers utilize data and models to solve unstructured problems. Basically, DSS is designed to support all stages of decision making starting from identifying problems, selecting relevant data, determining the approach used in the decision-making process, to evaluating alternative choices [2].

According to [3] Decision Support Systems (DSS) is a science that examines unique and interesting ideas in the process of designing and implementing a system.

\subsection{Analytical Hierarchy Process}

According to [4] AHP is a basic approach in decision making, which aimed at choosing the best choices from several alternatives by considering several criteria. In this process, the decision maker performs a simple pairwise comparison assessment which is then used to develop the overall system to rank alternative rankings.

The model consists of four major operations which include several steps below [5]:

1. Decision problem structure (hierarchy construction)

2. Making pair-wise comparison and obtaining judgment matrix.

3. Computing local weight and consistency of the comparisons.

4. Aggregation of local weight.

\subsection{Related Work}


Some previous researches have conducted in term of halal restaurant finding in town and AHP method [5],[6],[7], [8]. In [5] AHP was used to evaluate employees' performances based on five criteria: personal skills, initiatives, teaching quality, method of teaching and research in which case each of the criteria was divided into sub-criteria. The result obtained showed that the consistency ratio (CR) of the five criteria is C.R $=0.0976$ which showed that there is consistency in all the criteria in appraising the performance of an academic staff in Kampala International University (KIU).

Halal restaurant finding is the topic for [6] while this application was build using Geospatial Query on NOSQL Database. This research was able to find halal restaurant in several countries which Islam was minority religion in it, yet it still has not shown the restaurant information in detail, such as menu, price and review from other customer.

AHP method was also used in [7] and [8]. In [7] AHP was used to process criteria for major selecting in university. It was built on Android platform. Since it has no server in application, it was quite difficult to change the weight of each criteria.

\section{Research Methods}

\subsection{Collecting Data}

In building DSS in term of selecting halal-certified restaurant, we distributed questionnaire to 75 respondents in seeking the appropriate criteria for selecting halal-certified restaurant. We have price of food, variation of menu and service of restaurants. For alternatives of restaurants, we use 10 samples of halal-certified restaurant, which data are obtained from MUI websites and symbolized them as R1, R2, R3,.., R10.

\subsection{Modelling problem}

Decision support system usually implement a technique to process some criteria as input then transform them into output in the form of alternatives that will facilitate decision makers. Hence, we choose Analytical Hierarchy Process (AHP) which has been known to be reliable for processing data on DSS. AHP has been developed by Thomas L. Saaty [9]. AHP is a method that can be used in the decision support system or decision-making system by considering the factors of perception, preferences, experience and intuition. AHP incorporates judgments and personal values into a single logical way [10].

The hierarchy for this case is shown in Fig.1. There were 3 criteria for this DSS, namely food price, variations of menu and restaurant services. Those criteria were obtained from questionnaire that we did before. 


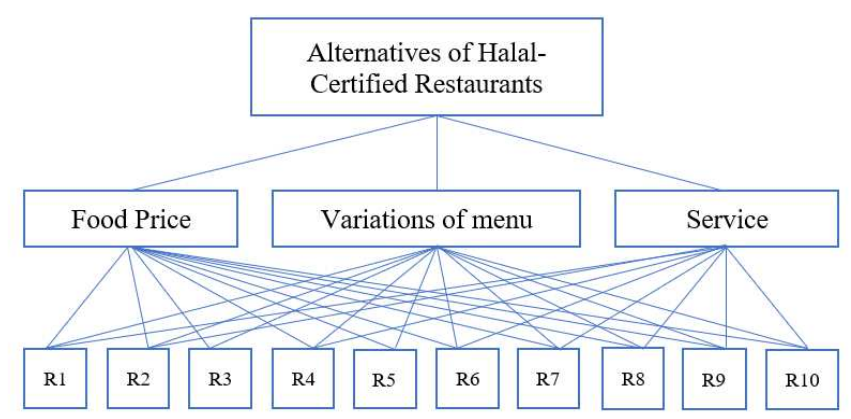

Fig.1 Decision Hierarchy

In this research, several stages of AHP are described below:

1. Structure the decision hierarchy, as seen at Fig.1

2. Provide assessment of alternative decision

3. Pairwise comparison of criteria

4. Calculate eigen value of these matrix

5. Calculate consistency index $(\mathrm{CI})$ and consistency ratio $(\mathrm{CR})$

6. Calculate rank of alternative

\subsection{System Development}

In this research, we use incremental method in system development. This model can be used when the development team's resources are limited. In its process, model is divided into smaller parts (software release). In addition, there is a feedback on each software release that makes user needs clearer. Incremental models can also minimize the risk of defects / bugs during the software development process because each review is carried out in stages. [11], [12]. Some phases in incremental method is described below [12]:

1. Communication phase

In this phase the problems are analyzed to find out the goals and objectives of the establishment of the system (LPPOM-MUI Jakarta). We collect information about this problem using questionnaire and interview. Questionnaire were distributed directly or through social media. There are 75 respondents from various ages, positions, and different profiles. To complete information seeking, interview to executive director of LPPOM MUI Jakarta was also conducted in term of halal-certified restaurant.

2. Planning phase

First step of planning phase is problem defining and finding solutions to problems. In this case, we were trying to develop an application in android platform which can give alternatives of halal certified restaurant in Jakarta to Moslem people. The second step of this phase is explaining the objective of system. As stated above, the objective is to develop a decision support system which implement AHP method for giving some alternatives of halal-certified restaurant.

3. Modelling phase

In modelling phase, we designed the system according to user's need. Here UML was used to ease the design phase.

4. Coding phase

After designing the system using UML, a DSS application was develop using programming language. 
5. Deployment phase

In this phase, this application was published to LPPOM MUI Jakarta to be evaluated.

\section{Result and Discussion}

\subsection{AHP Model}

Accordance to previous chapter, first we need to structure the decision hierarchy. To implement AHP in this case, pairwise comparison of criteria matrix must be defined first, as shown in Table I.

Table 1. Pairwise Comparison of Criteria

\begin{tabular}{|l|l|l|l|}
\hline Criteria & Price & Menu & Service \\
\hline Price & 1 & 0,333 & $1 / 0,333$ \\
\hline Menu & $1 / 0,333$ & 1 & 7 \\
\hline Service & 0,333 & $1 / 7$ & 1 \\
\hline
\end{tabular}

After that, matrix of criteria was transformed into normalized pairwise comparison of criteria matrix, as shown at Table II. For this case, we will get normalized value of price as 0,243 , value of menu variations as 0,669 and value of service as 0,088 .

Table 2. Normalized Matrix of Criteria

\begin{tabular}{|l|l|l|l|}
\hline Criteria & Price & Menu & Service \\
\hline Price & 1 & 0,333 & $1 / 0,333$ \\
\hline Menu & $1 / 0,333$ & 1 & 7 \\
\hline Service & 0,333 & $1 / 7$ & 1 \\
\hline
\end{tabular}

Next step is to calculate consistency value, that is eigen value calculating $\left(\lambda_{\max }\right)$, consistency index (CI) and consistency ratio (CR).

$$
\begin{aligned}
\lambda_{\max } & =(0,243 * 4,336)+(0,669 * 1,476)+(0,088 * 11,003)=3,011 \\
& \begin{aligned}
\mathrm{CI} & =\left(\lambda_{\max }-\mathrm{n}\right) /(\mathrm{n}-1) \\
& =(3,011-3) /(3-1) \\
& =0,005
\end{aligned}
\end{aligned}
$$

After obtaining CI value, the last step is calculating consistency ratio (CR).

$$
\begin{aligned}
\mathrm{CR} & =\mathrm{CI} / 0,58 \\
& =0,005 / 0,58 \\
& =0,009
\end{aligned}
$$


Since the value of CR is less than 0.1 , then we can conclude that it is consistent or in the other word the criteria chosen are feasible for use in decision making.

To calculating the best alternatives for DSS, weight of every criteria of each restaurant must be determined. Table III show the weight of criteria for each restaurant. Ten samples of halal-certified restaurant were used for examples.

Table 3. Weight of Criteria

\begin{tabular}{|c|c|c|c|}
\hline Alt & Price & Menu & Service \\
\hline R1 & Rp. 60000,- & 40 & 3 \\
\hline R2 & Rp. 62500,- & 94 & 4 \\
\hline R3 & Rp. 55000,- & 30 & 1 \\
\hline R4 & Rp. 50000,- & 81 & 8 \\
\hline R5 & Rp. 37500,- & 54 & 2 \\
\hline R6 & Rp. 60000,- & 72 & 5 \\
\hline R7 & Rp. 35000,- & 17 & 3 \\
\hline R8 & Rp. 15000,- & 84 & 3 \\
\hline R9 & Rp. 60000,- & 72 & 2 \\
\hline R10 & Rp. 50000,- & 23 & 3 \\
\hline
\end{tabular}

After defined weight of alternatives, comparison of alternatives and eigen value for each criterion were calculated. Eigen value was obtained from mean value of each alternatives on matrix comparison.

Table 4. Eigen Value

\begin{tabular}{|l|l|l|l|}
\hline Alt & Price & Menu & Service \\
\hline R1 & 0,124 & 0,071 & 0,088 \\
\hline R2 & 0,129 & 0,166 & 0,118 \\
\hline R3 & 0,113 & 0,053 & 0,029 \\
\hline R4 & 0,103 & 0,143 & 0,235 \\
\hline R5 & 0,077 & 0,096 & 0,059 \\
\hline R6 & 0,124 & 0,127 & 0,147 \\
\hline R7 & 0,072 & 0,041 & 0,088 \\
\hline R8 & 0,031 & 0,135 & 0,088 \\
\hline R9 & 0,124 & 0,127 & 0,059 \\
\hline R10 & 0,103 & 0,041 & 0,088 \\
\hline
\end{tabular}

To recommend several good alternatives to decision maker, eigen value (Table III) need to process furthermore, by multiplying those eigen value to eigen weight, as described in Fig 2 below. 


$\begin{array}{|lll|}$\cline { 4 - 4 } 0,124 & 0,071 & 0,088 \\ 0,129 & 0,166 & 0,118 \\ 0,113 & 0,053 & 0,029 \\ 0,103 & 0,143 & 0,235 \\ 0,077 & 0,096 & 0,059 \\ 0,124 & 0,127 & 0,147 \\ 0,072 & 0,041 & 0,088 \\ 0,031 & 0,135 & 0,088 \\ 0,124 & 0,127 & 0,059 \\ 0,103 & 0,041 & 0,088\end{array}$] \times\left[\begin{array}{l}0,243 \\ \mathbf{0 , 6 6 9} \\ 0,088\end{array}\right]=\left[\begin{array}{c}0,085 \\ \mathbf{0 , 1 5 3} \\ 0,066 \\ 0,142 \\ 0,088 \\ 0,128 \\ 0,052 \\ 0,106 \\ 0,120 \\ 0,060\end{array}\right]$

Fig. 2. Result of AHP Process

Thus, we can interpret the result in a sorted list from the best alternatives of halal-certified restaurant, as shown on table V. It can conclude that from the samples used, restaurant R2 is the best alternative for Moslem to come, in term of its price, variations of menu and services.

Table 4. Result of AHP Process

\begin{tabular}{|l|l|l|}
\hline Rank. & Restaurant & Weight \\
\hline 1. & R2 & 0,153 \\
\hline 2. & R4 & 0,142 \\
\hline 3. & R6 & 0,128 \\
\hline 4. & R9 & 0,120 \\
\hline 5. & R8 & 0,106 \\
\hline 6. & R5 & 0,088 \\
\hline 7. & R1 & 0,085 \\
\hline 8. & R3 & 0,066 \\
\hline 9. & R10 & 0,060 \\
\hline 10. & R7 & 0,052 \\
\hline
\end{tabular}

\subsection{Deployment phase}

In coding phase, all of design are translated into an application in android platform. Some capture below (Fig 3. Fig. 4 and Fig 5) of this system can represent the whole DSS.

This system evaluated to some respondents and give good feedback, that this application can help people in finding halal-certified restaurant and show the nearest restaurant to user's current location

As well as previous research [5], [7], [8], AHP gives good result in giving best alternatives for supporting decision making, AHP always calculate CI value first for checking 
whether the criteria used are feasible or not as main component for decision. It prevents AHP produce bad result or unfeasible recommendations.

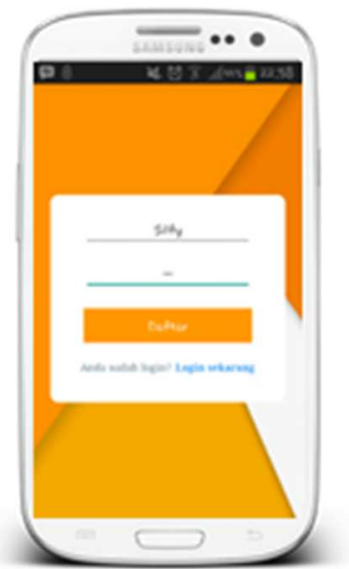

Fig. 3. Registration Menu

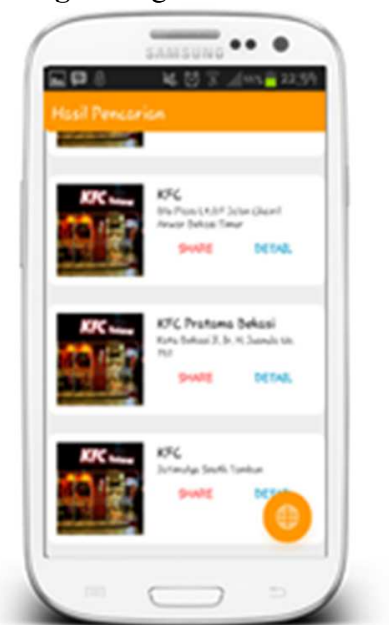

Fig. 4. Finding Restaurant Menu 


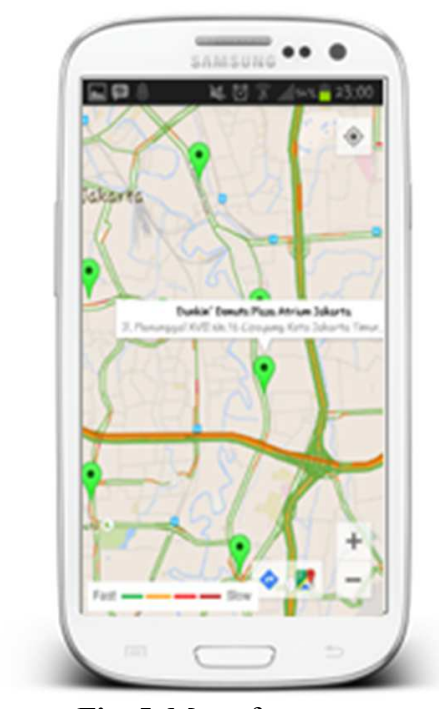

Fig. 5. Map of restaurant

\section{SUMMARY AND FURTHER WORK}

In this research, we distribute questionnaire to respondents to find out main criteria which will be used in selecting halal certified restaurant. From the questionnaire we found that user took higher priority on variations of menu $(66,9 \%)$, then price of food $(24,3 \%)$ and service of restaurant $(8,8 \%)$ when searching for halal-certified restaurant. These three points became criteria which used in DSS.

With respect to Consistency Ratio (CR) value of the criteria in this research, we found it results 0.009 in all criteria which is less than 0.1 . It means that all criteria are feasible to use in decision-making.

From the evaluation using unit testing, it can be concluded that this application was easy to use and could help Moslem people in Jakarta to search halal-certified restaurant.

To improve the result of this application, it was needed to enrich the database of halalcertified restaurant, not only in Jakarta region but also in all provinces in Indonesia.

Acknowledgements. This research supported by UIN Syarif Hidayatullah Conference Grant for ICONQUHAS 2019

\section{References}

[1] Saaty, Thomas L. 2012. Decision Making for Leaders, The Analytic Hierarchy Process for Decisions In A Complex World. RWS Publication.

[2] Magdalena, Hilyah. 2012. Sistem Pendukung Keputusan Untuk Menentukan Mahasiswa Lulusan Terbaik di Perguruan Tinggi (Studi Kasus STMIK Atma Luhur Pangkalpinang). Yogyakarta.

[3] Averweg, Udo Richard Franz. 2012. Decision-making Support Systems: Theory \& Practice. South Africa.

[4] Vargas, Saaty. 2012. Decision-making Support Systems: Theory \& Practice. 
[5] Fashoto S., Amaonwu, O., Aderenle, Afolorunsho, A. 2018. Development of A Decision Support System on Employee Performance Appraisal using AHP Model. International Journal on Informatics Visualization

[6] Haris, Luthfi. 2014. Aplikasi Pencarian Restoran Halal Terdekat dengan Memanfaatkan Geospatial Query pada NoSQL Database. Jakarta.

[7] Budiyanto, F.I.K. 2014. AHP (Analytical Hierarchy Process) Pemilihan Jurusan Perguruan Tinggi di Indonesia Berbasis Android Mobile. UIN Syarif Hidayatullah Jakarta. Unpublished.

[8] Wulandari, Novita E. 2015. Sistem Pendukung Keputusan Penentu Karyawan (Agen) Terbaik Menggunakan Metode Analytical Hierarchy Process (AHP). Jurnal Informatika Vol. 9 No. 3

[9] Saaty, T.L. 1980. The Analytic Hierarchy Process For Decision In A Complex World. RWS Publication.

[10] Kusumadewi, S. Hartati, A. Harjoko and R. Wardoyo. Fuzzy Multi - Attribute Decision Making (Fuzzy MADM), Graha Ilmu, Yogyakarta, (2006)]

[11] Pressman, S. Roger. 2010. Software Engineering: A Practitioner's Approach 7th Edition. New York: McGraw-Hill.

[12] Fanani, M.F, Sholiq, Muqtadiroh, F. 2015. Implementasi Metode Incremental Dalam Membangunaplikasi Use Case Point Pada Perusahaan DTS. Seminar Nasional Sistem Informasi Indonesia. 